\title{
Production, Characterization and Application of a Thermostable Tannase from Pestalotiopsis guepinii URM 7114
}

\author{
Amanda Reges de Sena ${ }^{1,2}$, Ana Claúdia de Barros dos Santos ${ }^{1}$, \\ Miquéas Jamesse Gouveia ${ }^{1}$, Marcelo Rodrigues Figueira de Mello ${ }^{1}$, \\ Tonny Cley Campos Leite ${ }^{3}$, Keila Aparecida Moreira and Sandra Aparecida de Assis ${ }^{2 *}$ \\ ${ }^{1}$ Microbiology Laboratory, Federal Institute of Education, Science and Technology of Pernambuco, \\ Campus Barreiros, 55560-000 Barreiros, PE, Brazil \\ ${ }^{2}$ Laboratory of Enzymology, Department of Health, State University of Feira de Santana, \\ 44036-900 Feira de Santana, BA, Brazil \\ ${ }^{3}$ Bioassays Laboratory for Drug Research, Federal University of Pernambuco, 50670-420 Recife, PE, Brazil \\ ${ }^{4}$ Central Laboratory of Garanhuns, Laboratory of Biotechnology, Academic Unit of Garanhuns, \\ Federal Rural University of Pernambuco, 55292-270 Garanhuns, PE, Brazil
}

Received: May 28, 2014

Accepted: September 17, 2014

\begin{abstract}
Summary
Tannase (EC 3.1.1.20) is an enzyme that hydrolyzes the ester and depside bonds of tannic acid to gallic acid and glucose. In the production of foods and beverages, it contributes to the removal of the undesirable effects of tannins. The aim of this study is to investigate the potential of endophytic fungi isolated from jamun (Syzygium cumini (L.) Skeels) leaves, and identified as Pestalotiopsis guepinii, in the production of tannase. Tannase was produced extracellularly by P. guepinii under submerged, slurry-state and solid-state fermentations. The submerged fermentation was found to be the most promising $(98.6 \mathrm{U} / \mathrm{mL})$. Response surface methodology was employed to evaluate the effect of variables $(\mathrm{pH}$ and temperature), and the results showed that the best conditions for tannase activity were $\mathrm{pH}=6.9$ and $30^{\circ} \mathrm{C}$. $K_{\mathrm{m}}$ was found to be $7.18 \cdot 10^{-4} \mathrm{~mol} / \mathrm{L}$ and $v_{\max }=250.00 \mathrm{U} / \mathrm{mL}$. The tannase activity was the highest in the presence of $\mathrm{Ca}^{2+}$ at a concentration of $5 \cdot 10^{-3} \mathrm{~mol} / \mathrm{L}$. Moreover, the enzyme was not inhibited by the tested chelators and detergents. The stability of the enzyme was also studied, and crude enzyme was evaluated in simulation of gastrointestinal digestion of monogastric animals. The crude enzyme was highly stable under simulated conditions; it retained $87.3 \%$ of its original activity after $6 \mathrm{~h}$. The study contributes to the identification of microbial species that produce tannase, with potential application in biotechnology.
\end{abstract}

Key words: endophytic fungus, Pestalotiopsis guepinii, submerged fermentation, animal feed, tannin acyl hydrolase (tannase)

\section{Introduction}

Jamun, also known as jambolan or purple olive, is a plant species belonging to the family Myrtaceae. Native to India, Ceylon, Malaysia and Australia (1), it has been widely grown as an ornamental plant, mainly along the coast, and it can be found in several Brazilian states such as Minas Gerais, Rio de Janeiro and São Paulo (2). Several studies have determined the presence of hydrolysable tannins in the plant, particularly in the seeds, increasing the chance of obtaining endophytic microorganisms that 
produce tannase (3-5). Tannins can also be found in the sap, fruits, leaves, skin and root system (6). It is noteworthy that the level and type vary according to the climate and geography of the environment, not only from one plant to another but also from one part of the same plant to another (7).

Tannin acyl hydrolase (TAH, EC 3.1.1.20), known as tannase, is an intracellular or extracellular inducible enzyme produced in the presence of tannic acid by bacteria, moulds and yeasts (6). In addition to these sources, it can be produced by animals and tannin-rich plants $(8,9)$. This enzyme catalyzes the hydrolysis of ester and depside bonds of hydrolysable tannins (10). Tannic acid, for example, is a hydrolysable tannin, which can be hydrolyzed by tannase to gallic acid and glucose. Among its applications are: preparation of instant tea (8), manufacture of beverages (juices, beer and wine) (11), production of gallic and ellagic acids (12), ester synthesis and effluent processing (13), and as an additive for animal feed (14).

Tannase is applied for the treatment of tannin-rich plants in the production of animal feed. If they are first treated with tannase, tannin content is decreased and this can then be used as complement in animal diet. Tannase utilization can be carried out in two ways: direct contact of enzymatic extracts with the material to hydrolyze the polyphenols and avoid their unpleasant polymerization, or growing tannase-producing fungal strains on tannin-rich materials, which are degraded to simpler compounds (15).

The most important means for obtaining tannase is the use of microorganisms, because they can produce enzymes continuously and in large quantities; in addition, the enzymes thus obtained are more stable compared to those obtained by other means (10). The main genera of fungi known as producers of tannase are Aspergillus, Penicillium, Fusarium and Trichoderma $(16,17)$.

Endophytic fungi are those that spend part or all of their life cycle colonizing inter- or intracellular spaces of living tissues of a host plant, in which they have different interactions without, however, causing negative effects $(18,19)$. The study of endophytes in tropical plants has received much attention lately, possibly due to the diversity, excellent source potential of new biologically active compounds, and benefits they can provide to plants (20).

The genus Pestalotiopsis is interesting not only as a plant pathogen but also as a commonly isolated endophyte (9). P. guepinii is a generic type of Pestalotiopsis sp., which is a plant pathogen that causes disease in important crop plants (21). The genus has been investigated not because of its pathogenic nature (22-24), but rather because its species produces many important secondary metabolites $(25,26)$ that may have medicinal, agricultural and industrial applications (9). Among them are: bioactive alkaloids, terpenoids, isocoumarin derivatives, coumarins, chromones, quinones, semiquinones, peptides, xanthones, xanthone derivatives, phenols, phenolic acids, and lactones with a range of antifungal, antimicrobial, and antitumour activities (26). However, some researchers (27) have also shown the potential of Pestalotiopsis sp. to produce enzymes such as cellulase, pectinase, xylanase and protease.
In this study, we analyze the production, characterization and application of extracellular tannase from Pestalotiopsis guepinii URM 7114, an endophytic fungus isolated from jamun (Syzygium cumini (L.) Skeels) leaves.

\section{Material and Methods}

\section{Reagents}

Tannic acid, gallic acid, and rodhanine were purchased from Sigma-Aldrich (Sigma Chemical Co., St. Louis, MO, USA). All the other chemicals used were of high quality analytical grade.

\section{Microorganism and its maintenance}

The fungus Pestalotiopsis guepinii isolated from the jamun (Syzygium cumini (L.) Skeels) leaves obtained from the Federal Institute of Education, Science and Technology of Pernambuco, Campus Barreiros, Brazil, was preserved in a bottle containing sterile distilled water and maintained on potato dextrose agar (PDA; HiMedia, Mumbai, India) slants at $4{ }^{\circ} \mathrm{C}$. Initially the fungus was screened for its ability to degrade tannic acid. The fungus was identified and deposited in Collection of Fungal Cultures, Department of Mycology, Federal University of Pernambuco, Brazil, under number URM 7114.

\section{Tannin-rich agro residues}

Pomegranate seeds (Punica granatum) were washed twice with distilled water. Then they were dried at $60^{\circ} \mathrm{C}$ in hot air oven for $24 \mathrm{~h}$ and maintained at room temperature in a dry place. The fruits were purchased from local supermarkets.

\section{Influence of the type of fermentation on the production of tannase by Pestalotiopsis guepinii URM 7114}

\section{Submerged fermentation}

Pestalotiopsis guepinii URM 7114 was grown on PDA, $\mathrm{pH}=6.8$, for 11 days at $28{ }^{\circ} \mathrm{C}$ in biochemical oxygen demand (BOD) incubator (Cienlab, Campinas, Brazil). The production of the enzyme was done in 250-mL Erlenmeyer flasks containing $50 \mathrm{~mL}$ of fermentation medium based on Czapeck-Dox broth containing (in g/L): $\mathrm{NaNO}_{3} 3, \mathrm{KCl}$ $0.5, \mathrm{MgSO}_{4} \cdot 7 \mathrm{H}_{2} \mathrm{O} 0.5, \mathrm{FeSO}_{4} \cdot 7 \mathrm{H}_{2} \mathrm{O} 0.01, \mathrm{~K}_{2} \mathrm{HPO}_{4} \cdot 3 \mathrm{H}_{2} \mathrm{O}$ 1.301 and pomegranate seed 30. After cooling the flask to room temperature, tannic acid ( $2 \%$, by mass per volume) was added after sterilisation through a $0.22-\mu \mathrm{m}$ membrane filter, the content was inoculated with three mycelial disks of $P$. guepinii $(1.3 \mathrm{~cm})$ and then incubated at 30 ${ }^{\circ} \mathrm{C}$, under shaking $(150 \times g)$ for $48 \mathrm{~h}$.

At the end of incubation, the cell-free filtrate was obtained by filtering through Whatman no. 1 filter paper. The filtrate was centrifuged (Sorvall, Hanau, Germany) at $3400 \times g$ for $14 \mathrm{~min}$ at $4^{\circ} \mathrm{C}$ and it served as a crude enzyme preparation.

\section{Solid-state fermentation}

Pestalotiopsis guepinii URM 7114 was grown on PDA, $\mathrm{pH}=6.8$, for 11 days at $28^{\circ} \mathrm{C}$ in BOD incubator (Cienlab). A mass of $5 \mathrm{~g}$ of pomegranate seeds was added to $250-\mathrm{mL}$ 
Erlenmeyer flasks and moistened with $5 \mathrm{~mL}$ of Czapeck-Dox medium. After cooling the flask to room temperature, tannic acid (2\%) was added through a $0.22-\mu \mathrm{m}$ membrane filter, the content was inoculated with three mycelial disks of $P$. guepinii $(1.3 \mathrm{~cm})$ and then incubated at $30{ }^{\circ} \mathrm{C}$ for $48 \mathrm{~h}$.

At the end of incubation, a suitable amount of the fermented matter was thoroughly mixed with $10 \mathrm{~mL}$ of citrate buffer $(0.05 \mathrm{~mol} / \mathrm{L}, \mathrm{pH}=5.0)$ by keeping the flasks on a rotary shaker for $1 \mathrm{~h}$ at $150 \times g$. The mixture was filtered through a muslin cloth, the filtrate was centrifuged (Sorvall) at $3400 \times g$ for $14 \mathrm{~min}$ at $4{ }^{\circ} \mathrm{C}$ and it served as crude enzyme preparation.

\section{Slurry-state fermentation}

Pestalotiopsis guepinii URM 7114 was grown on PDA, $\mathrm{pH}=6.8$, for 11 days at $28^{\circ} \mathrm{C}$ in BOD incubator (Cienlab). A mass of $5 \mathrm{~g}$ of the pomegranate seeds was added to 250 -mL Erlenmeyer flask and moistened with $45 \mathrm{~mL}$ of distilled water and $5 \mathrm{~mL}$ of Czapeck-Dox medium. After cooling the flask to room temperature, tannic acid (2\%) was added through a $0.22-\mu \mathrm{m}$ membrane filter, the content was inoculated with 3 mycelial disks of $P$. guepinii $(1.3 \mathrm{~cm})$ and then incubated at $30{ }^{\circ} \mathrm{C}$, under shaking at $150 \times g$ for $48 \mathrm{~h}$. All tests were performed in triplicate.

At the end of incubation, a suitable amount of the fermented matter was thoroughly mixed with $10 \mathrm{~mL}$ of citrate buffer $(0.05 \mathrm{~mol} / \mathrm{L}, \mathrm{pH}=5.0)$ by keeping the flasks on a rotary shaker at $150 \times g$ for $1 \mathrm{~h}$. The mixture was filtered through a muslin cloth and the filtrate was centrifuged (Sorvall, Hanau, Germany) at $3400 \times g$ for $14 \mathrm{~min}$ at $4{ }^{\circ} \mathrm{C}$ and it served as crude enzyme preparation. All tests were performed in triplicate and average values (which differed by $<5 \%$ ) were calculated.

\section{Tannase assay}

The tannase activity was estimated by a modified method using ethanolic rhodanine and tannic acid as substrates in $0.05 \mathrm{~mol} / \mathrm{L}$ of citrate buffer $(\mathrm{pH}=5.0)(28,29)$. The tannase activity $(\mathrm{U} / \mathrm{mL})$ was defined as the amount of enzyme required to produce $1 \mu \mathrm{mol}$ of gallic acid per minute under the assay conditions. All tests were performed in triplicate.

\section{Response surface optimization of temperature and $\mathrm{pH}$}

Response surface modelling was applied to determine the optimum temperature and $\mathrm{pH}$ for the production of tannase in submerged fermentation. The experimental design with two variables (temperature and $\mathrm{pH}$ ) and three replicates at the centre of the domain leading to a total of nine experiments was used to investigate the effect of temperature and $\mathrm{pH}$ on the tannase activity. The $\mathrm{pH}$ was studied at three levels $(6.5,7.0$ and 7.5), and temperature at five levels $\left(20,25,30,35\right.$ and $\left.40{ }^{\circ} \mathrm{C}\right)$. The experimental errors were evaluated from the replication of the centre point.

\section{Effect of metal ions, surfactants and chelator on tannase activity}

The effect of $\mathrm{Na}^{+}, \mathrm{K}^{+}, \mathrm{Ca}^{2+}, \mathrm{Mg}^{2+}$ and $\mathrm{Mn}^{2+}$ on tannase activity was investigated. The following concentrations of metal ions were used: $10^{-3}$ and $5 \cdot 10^{-3} \mathrm{~mol} / \mathrm{L}$. The effects of
Tween 20, Tween 80 and sodium dodecyl sulphate (SDS) at a volume fraction of $1 \%$ and chelator ethylenediaminetetraacetic acid (EDTA) at a concentration of $10^{-3} \mathrm{~mol} / \mathrm{L}$ were studied. Tannase activity was determined using the previously described assay (tannase assay). The activity of the enzyme without any metal ions, surfactant or chelator treatment was taken as control and it was considered as $100 \%$.

\section{Determination of kinetic parameters}

To obtain the Michaelis-Menten kinetic parameters of tannase for the hydrolysis of tannic acid, $250 \mu \mathrm{L}$ of tannic acid (from $1.8 \cdot 10^{-4}$ to $3.0 \cdot 10^{-4} \mathrm{~mol} / \mathrm{L}$ ) were dissolved in 0.05 $\mathrm{mol} / \mathrm{L}$ of citrate buffer $(\mathrm{pH}=5.0)$, added to $250 \mu \mathrm{L}$ of tannase and incubated at $30^{\circ} \mathrm{C}$ for $5 \mathrm{~min}$. The $K_{\mathrm{m}}$ and $v_{\max }$ for tannic acid were determined using Lineweaver-Burk plots.

\section{Thermal stability of tannase}

To test the stability of the enzyme at high temperatures, the samples of tannase in test tubes of uniform size were incubated in water at different temperatures $(30,40$, $50,60,70,80$ and $\left.90^{\circ} \mathrm{C}\right)$ and different amounts of time $(0$, $10,20,30,40,50$ and $60 \mathrm{~min})$. After heating, the tubes were cooled in an ice bath, and the residual activity measurement was carried out at $\mathrm{pH}=5.0$ and $30^{\circ} \mathrm{C}$.

\section{Effect of simulated upper monogastric digestive tract conditions on tannase activity}

The effect of simulated monogastric digestive tract conditions was determined in vitro $(30,31)$. In the first test, residual tannase activity was determined after coincubation $\left(100 \times g\right.$ at $\left.39^{\circ} \mathrm{C}\right)$ of the $P$. guepinii enzyme with pepsin ( $1 \%$, by mass per volume) at $\mathrm{pH}=2.5$ for $2 \mathrm{~h}$ to simulate gastric digestion. In the second test, pancreatin $(1 \%$, by mass per volume) and bile extract ( $1 \%$, by mass per volume) were used to simulate enteric digestion. The enzymatic extract was incubated under the same conditions as in the previous test, but at $\mathrm{pH}=6.8$ for $4 \mathrm{~h}$. In the third test, simulation of intestinal digestion, residual activity was determined after coincubation, as described above, of the P. guepinii enzyme with trypsin ( $1 \%$, by mass per volume) and taurocholic acid ( $1 \%$, by mass per volume) for $4 \mathrm{~h}$. Total digestion was simulated by adding pepsin at $\mathrm{pH}=2.5$ for $2 \mathrm{~h}$, followed by incubation with pancreatin and bile extract at $\mathrm{pH}=6.8$ for $4 \mathrm{~h}$, all together taking $6 \mathrm{~h}$. Each test had its respective controls, consisting only of water and enzymatic extract.

\section{Statistical analysis}

The experimental data were processed using the STATISTICA software, v. 7.0 (StatSoft, Inc., Tulsa, OK, USA) to indicate the variables with statistically significant effects $(\mathrm{p}<0.05)$, and the model fitted to the experimental data. All the experiments were carried out in a random order. To estimate the lack of fit of the model to the experimental data, an analysis of variance (ANOVA) was performed.

\section{Results and Discussion}

\section{Influence of different fermentations on tannase production}

No previous studies could be found that describe the production or characterization of a tannic acid degrading 
the enzyme from Pestalotiopsis guepinii and adopt different fermentation protocols. The influence of the type of fermentation on the production of tannase was examined using submerged (SmF), solid-state (SSF) and slurry-state fermentations (SLSF). Tannase activity was recorded in all fermentation protocols. The highest enzyme yield was registered in submerged fermentation compared to solid-state (production and productivity 11.40 times higher) and slurry-state fermentation (Table 1). These disparities in behaviour can be related to differences in aeration and inoculum form.

Table 1. Tannase activity in different fermentation processes

\begin{tabular}{cc}
\hline Fermentation & Tannase activity/(U/mL) \\
\hline Submerged & $(98.6 \pm 0.2)^{\mathrm{a}}$ \\
Solid-state & $(8.6 \pm 0.9)^{\mathrm{c}}$ \\
Slurry-state & $(22.9 \pm 0.2)^{\mathrm{b}}$ \\
\hline
\end{tabular}

Mean values followed by different letters differ at a level of $5 \%$ of probability by Tukey's test

Hamdy and Fawzy (32) measured tannase activity in solid-state $(9.14 \mathrm{U} / \mathrm{mL})$, slurry-state $(6.49 \mathrm{U} / \mathrm{mL})$ and submerged fermentations $(9.02 \mathrm{U} / \mathrm{mL})$ produced by $A$. niger. Higher productivity of tannase was obtained in SSF than $\mathrm{SmF}$ in research developed by Renovato et al. (33). On the other hand, Srivastava and Kar (34) stated that extracellular tannase was optimally produced in submerged cultures by $A$. niger.

\section{Optimization of temperature and $\mathrm{pH}$ for tannase production}

Table 2 shows the Doehlert design applied for the optimization of temperature and $\mathrm{pH}$ for tannase production by endophytic fungus Pestalotiopsis guepinii URM 7114. The influence of temperature and $\mathrm{pH}$ on the activity of the enzyme was investigated using response surface methodology. The results are shown in Figs. 1 and 2.

Table 2. Results of the Doehlert design for the optimization of temperature and $\mathrm{pH}$ for tannase activity from Pestalotiopsis guepinii UMR 7114

\begin{tabular}{|c|c|c|c|}
\hline \multirow{2}{*}{ Run } & \multirow{2}{*}{$\mathrm{pH}$} & Temperature & Experimental tannase activity \\
\hline & & ${ }^{\circ} \mathrm{C}$ & $\mathrm{U} / \mathrm{mL}$ \\
\hline 1 & 7.5 & 25 & $41.2 \pm 1.3$ \\
\hline 2 & 7.5 & 35 & $50.54 \pm 0.00$ \\
\hline 3 & 7.0 & 20 & $45.53 \pm 0.00$ \\
\hline 4 & 7.0 & 30 & $57.3 \pm 1.0$ \\
\hline 5 & 7.0 & 30 & $57.7 \pm 1.0$ \\
\hline 6 & 7.0 & 30 & $57.44 \pm 0.09$ \\
\hline 7 & 7.0 & 40 & $51.15 \pm 0.00$ \\
\hline 8 & 6.5 & 25 & $53.6 \pm 2.0$ \\
\hline 9 & 6.5 & 35 & $50.2 \pm 1.2$ \\
\hline
\end{tabular}

The regression model provided for the enzyme activity in relation to $\mathrm{pH}$ and temperature in the experimental design is expressed by Eq. 1:

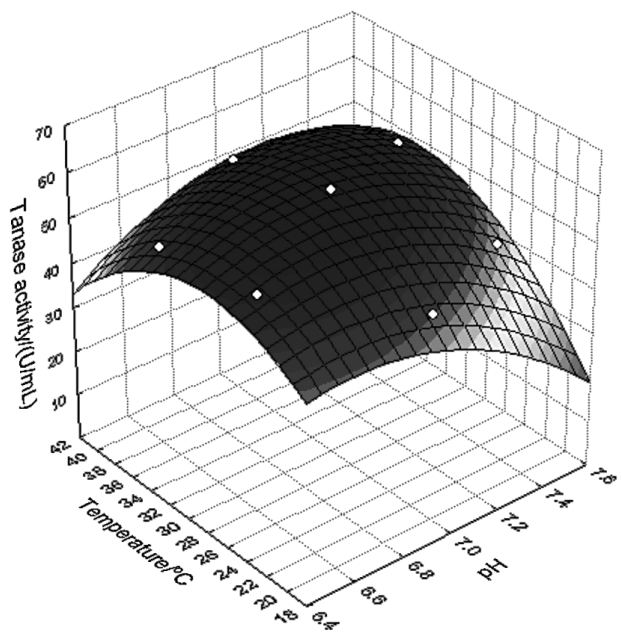

Fig. 1. Response surface plot for tannase activity from Pestalotiopsis guepinii URM 7114 according to the experimental design and model in Table 2. The three-dimensional plot shows the influence of incubation temperature and $\mathrm{pH}$ on tannase production

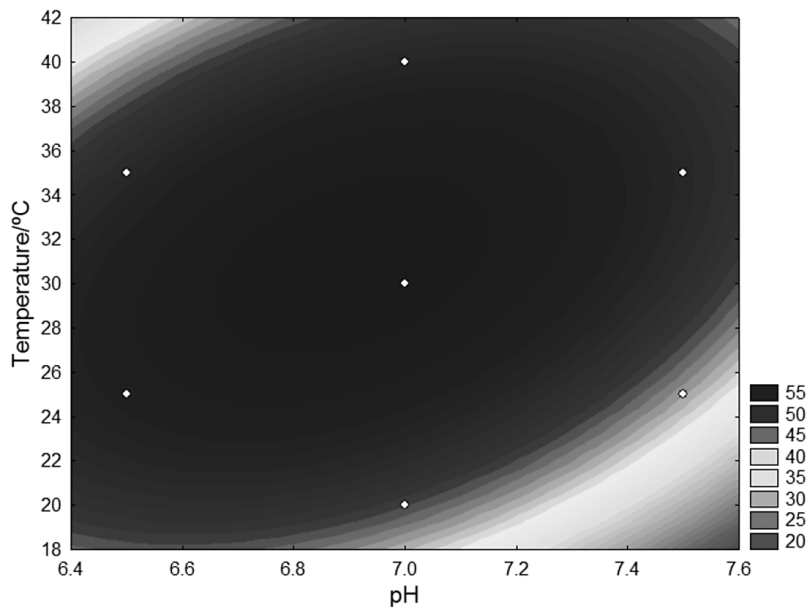

Fig. 2. Isoresponse contour plot of $\mathrm{pH}$ and temperature for tannase activity from Pestalotiopsis guepinii URM 7114

$$
\begin{gathered}
Y=-958.29( \pm 26.51)+308.87 \cdot X( \pm 7.23)-25.25 \cdot X_{1}^{2} \\
( \pm 0.51)-3.22 \cdot X_{2}( \pm 0.28)-0.091 \cdot X_{2}^{2}( \pm 0.0017)+ \\
+1.28 \cdot X_{1} \cdot X_{2}( \pm 0.037)+0
\end{gathered}
$$

where $\mathrm{Y}$ is the predicted response (tannase activity), $\mathrm{X}_{1}$ is the $\mathrm{pH}$ and $\mathrm{X}_{2}$ the temperature.

The temperature and $\mathrm{pH}$ affect many metabolic processes such as protein denaturation, enzyme inhibition, promotion or inhibition of a particular metabolite, cell death, etc. (4). Eq. 1 illustrates the relationship of these two variables with the enzyme activity. Through the derivation of this equation, the points of maximum enzymatic activity can be obtained. According to this method, the optimal $\mathrm{pH}$ and temperature values were 6.9 and 30.87 ${ }^{\circ} \mathrm{C}$, respectively.

Similar values were found by Qiu et al. (35), Riul et al. (36) and da Costa et al. (37), who studied tannase from Penicillium herquei, Aspergillus phoenicis and Aspergillus tamarii respectively, relative to temperature. Battestin and Macedo (11) determined that optimum $\mathrm{pH}$ was between 
4.5 and 6.0 for tannase production by Paecilomyces variotii. Selwal and Selwal (38) studied Penicillium atramentosum tannase and found that the enzyme exhibits optimal activity at $\mathrm{pH}=7.5$.

The Pareto chart (Fig. 3) shows that the temperature and $\mathrm{pH}$ variables, both linear and quadratic terms, are significant for the tannase activity because their $p$-value is less than 0.05 .

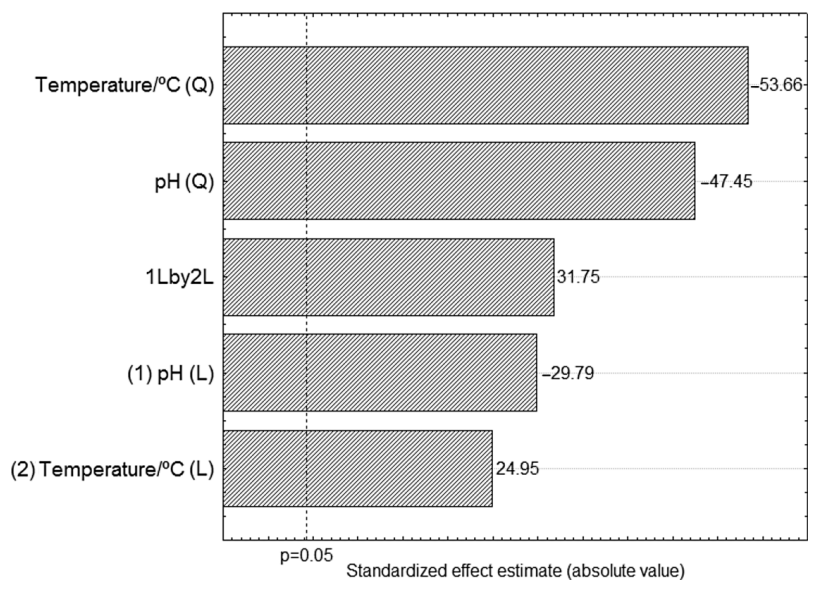

Fig. 3. Pareto chart showing the significance of variables temperature and $\mathrm{pH}$ for tannase activity from Pestalotiopsis guepinii URM 7114. $\mathrm{L}=$ linear, $\mathrm{Q}=$ quadratic term

ANOVA was applied using the experimental data to evaluate the fit of the quadratic model (Table 3). A test based on the Fisher distribution (F-test) indicated that the fitted equation is statistically significant $(\mathrm{F}=892.82>9.01)$. A lack-of-fit sum of squares $(\mathrm{F}=2.57<18.51)$ indicates that there is a good agreement between the model's predicted response and the experimental values studied for each variable.

\section{Effect of metal ions and other chemicals}

The effect of cations, chelator and detergents on tannase activity was investigated and shown in Table 4 . Studying the influence of monovalent cations on the activity of the tannase showed that $\mathrm{K}^{+}$had an activating effect that was greater than that seen with $\mathrm{Na}^{+}$cations at a concentration of $5 \cdot 10^{-3} \mathrm{~mol} / \mathrm{L}$. Similar results were reported by Sabu et al. (39), who found that tannase from Aspergillus niger ATCC 16620 was activated by $\mathrm{K}^{+}$ions.

Tannase was only marginally inhibited by certain cations, including $\mathrm{Mg}^{2+}$ and $\mathrm{Mn}^{2+}$, at a concentration of $5 \cdot 10^{-3}$ and $10^{-3} \mathrm{~mol} / \mathrm{L}$, respectively. However, the enzyme was
Table 4. Effect of metal ions, surfactants and chelator on tannase activity

\begin{tabular}{lcc}
\hline \multicolumn{1}{c}{ Compound } & \multicolumn{2}{c}{ Relative activity/\% } \\
\hline$c($ metal ion $) /(\mathrm{mol} / \mathrm{L})$ & $10^{-3}$ & $5 \cdot 10^{-3}$ \\
Control & 100 & 100 \\
$\mathrm{NaCl}$ & $77.8 \pm 0.5$ & $72.6 \pm 0.2$ \\
$\mathrm{KCl}$ & $68.1 \pm 2.3$ & $98.8 \pm 1.6$ \\
$\mathrm{CaCl}_{2}$ & $136.7 \pm 0.9$ & $143.5 \pm 0.2$ \\
$\mathrm{MgCl}_{2}$ & $103.6 \pm 4.2$ & $95.66 \pm 0.00$ \\
$\mathrm{MnCl}_{2}$ & $75.0 \pm 1.6$ & $138.66 \pm 0.08$
\end{tabular}

$\varphi($ surfactant $)=1 \%$

Control

Tween 20

Tween 80

SDS

$c$ (chelator $)=10^{-3} \mathrm{~mol} / \mathrm{L}$

Control

EDTA

$146.5 \pm 5.5$

activated by $\mathrm{Ca}^{2+}$ ions. Our results were similar to those observed by other researchers (40) who reported small loss in residual activity using $\mathrm{Mg}^{2+}$ and $\mathrm{Mn}^{2+}$ at the same concentrations. On the other hand, $\mathrm{Ca}^{2+}$ inhibited the activity of Penicillium verrucosum tannase (41).

Many enzymes, such as xylose isomerase or $\alpha$-amylases, require metal ion activators in order to achieve full catalytic efficiency. On the other hand, some enzymes are inhibited by metal ions and several other organic compounds $(37,42,43)$. It seems thus that these metal ions are necessary for the catalytic activity of tannase.

The activity was found to increase with the addition of Tween 20, Tween 80, sodium dodecyl sulphate (SDS) and ethylenediaminetetraacetic acid (EDTA) (Table 4). No inhibition by EDTA was observed in the case of the tannase from Aspergillus flavus (44) and yeast tannase (45). The SDS and Tween 80 had no effect on tannase activity in research by Iqbal and Kapoor (46).

In contrast, tannase produced by Aspergillus ochraceus was inhibited by EDTA at a concentration of $10^{-3} \mathrm{~mol} / \mathrm{L}$ (47). The presence of chelator EDTA and surfactants also inhibited the tannase from Paecilomyces variotii and Aspergillus aculeatus $(11,48)$. Considering that the use of certain compounds can be advantageous in various industrial enzymatic processes, the resistance of enzymes to this kind of compounds is desirable (37).

Table 3. Analysis of variance (ANOVA) for the quadratic model fitted to the data from Table 2

\begin{tabular}{|c|c|c|c|c|c|c|}
\hline Variation source & Sum of squares & Degree of freedom & Mean square & F & Tabulated F (IC=95\%) & $\mathrm{R}^{2}$ \\
\hline Regression & 278.56 & 5 & 55.712 & 892.82 & 9.01 & \\
\hline Residual & 0.19 & 3 & 0.0624 & & & \\
\hline Lack-of-fit & 0.11 & 1 & 0.1053 & 2.57 & 18.51 & 0.9993 \\
\hline Pure error & 0.08 & 2 & 0.0410 & & & \\
\hline Total & 278.75 & 8 & & & & \\
\hline
\end{tabular}




\section{Determination of Michaelis-Menten constants}

To see the effect of substrate concentration on tannase activity, an assay was performed at various concentrations of tannic acid. The Lineweaver-Burk plot showed that the $K_{\mathrm{m}}$ and $v_{\max }$ values of tannase were $7.18 \cdot 10^{-4} \mathrm{~mol} / \mathrm{L}$ and $250.00 \mathrm{U} / \mathrm{mL}$, respectively (Fig. 4).

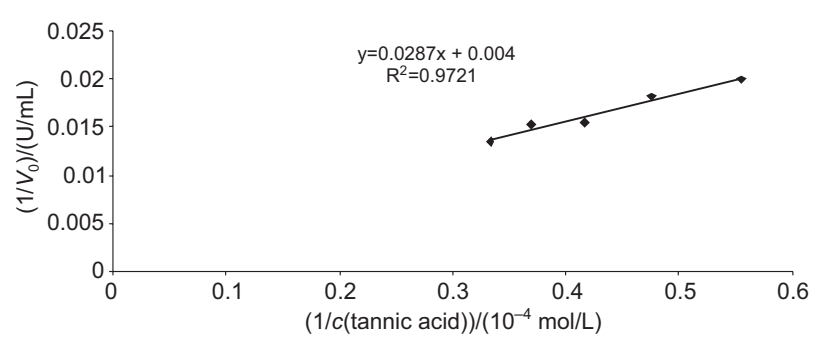

Fig. 4. Lineweaver-Burk plots of the hydrolysis of tannic acid by tannase from Pestalotiopsis guepinii URM 7114

The values of kinetic constants $\left(K_{\mathrm{m}}\right.$ and $\left.v_{\max }\right)$ depend on the particular substrate used and the enzyme source (49). In this work, $v_{\max }$ value of $250.00 \mathrm{U} / \mathrm{mL}$ was higher than that reported by other authors, $17.09 \mathrm{U} / \mathrm{mL}$ (50). The $K_{\mathrm{m}}$ value for tannase from Aspergillus niger using tannic acid as substrate was found to be $0.40 \cdot 10^{-3} \mathrm{~mol} / \mathrm{L}(51)$. Moreover, tannase produced by Emericella nidulans has a $K_{\mathrm{m}}$ value of $14.01 \cdot 10^{-3} \mathrm{~mol} / \mathrm{L}$ (52). This implies that tannase produced by Pestalotiopsis guepinii URM 7114 has higher affinity for tannic acid.

\section{Tannase thermal stability}

Thermal stability is an important characteristic of many enzymes with biotechnological application. The crude extract of tannase from Pestalotiopsis guepinii URM 7114 was stable in a temperature range from 30 to $90{ }^{\circ} \mathrm{C}$ (Fig. 5). In this work, the tannase retained 93.5 and $91.4 \%$ of its original activity after $60 \mathrm{~min}$ of incubation at 30 and $90{ }^{\circ} \mathrm{C}$, respectively. Moreover, the enzyme was more stable at $50{ }^{\circ} \mathrm{C}$ throughout the period, ranging between 100 and $129.20 \%$ residual activity.

Similar thermal stabilities of tannase from several other fungal species have been reported. The crude tannase from Paecilomyces variotii was stable in a temperature range from 20 to $50{ }^{\circ} \mathrm{C}$, in which it retained 99 and $96 \%$ residual activity at 20 and $50{ }^{\circ} \mathrm{C}$, respectively (13). The

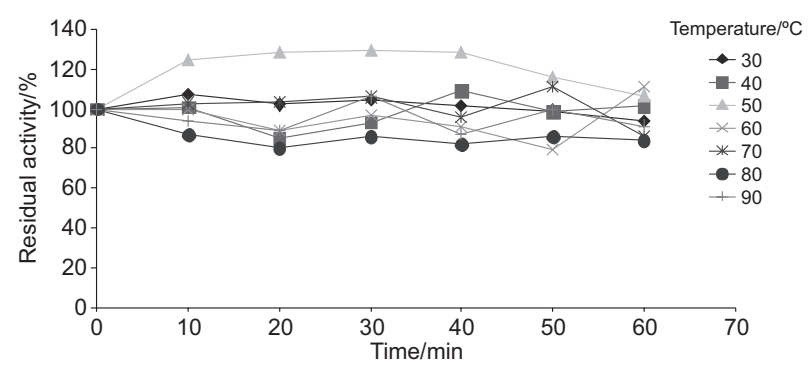

Fig. 5. Effect of temperature on the stability of tannase from Pestalotiopsis guepinii URM 7114. All reactions were carried out in $0.05 \mathrm{~mol} / \mathrm{L}$ of citrate buffer $(\mathrm{pH}=5.0)$ in the range of $30-90{ }^{\circ} \mathrm{C}$ for $5 \mathrm{~min}$. The percentage of residual tannase activity was determined under standard assay conditions thermal stability profile of crude tannase from Penicillium notatum NCIM 923 revealed that above $95 \%$ was retained at $40{ }^{\circ} \mathrm{C}$ (53). On the other hand, the tannases from $A$. niger AUMC 4301 and Aspergillus flavus $(54,55)$ were thermally less stable than the enzyme described in the present study. The thermal stability of Pestalotiopsis guepinii URM 7114 is quite interesting, since some processes that use tannase need to be performed at elevated temperatures.

\section{Simulation of in vitro digestion}

Tannase produced in this study showed satisfactory residual activity in the presence of digestive enzymes from monogastric animals. After the in vitro exposure to simulated gastric conditions, $\mathrm{pH}=2.5$ for $2 \mathrm{~h}$, the tannase retained $141.4 \%$, while in the second test, which simulated enteric digestion, the enzyme exhibited $120.3 \%$ of its original activity. The influence of tripsin and total digestion were also evaluated (Table 5).

Table 5. Residual activity of the enzyme produced by Pestalotiopsis guepinii URM 7114 under in vitro simulation of gastrointestinal digestion of monogastric animals

\begin{tabular}{lc}
\hline \multicolumn{1}{c}{ Assay } & Residual activity/\% \\
\hline Pepsin+HCl $(2 \mathrm{~h})$ & $141.4 \pm 3.9$ \\
Pancreatin and bile extract $(4 \mathrm{~h})$ & $120.3 \pm 1.2$ \\
Tripsin+taurocholic acid $(4 \mathrm{~h})$ & $133.2 \pm 5.3$ \\
Total digestion $(6 \mathrm{~h})$ & $87.3 \pm 4.7$ \\
\hline
\end{tabular}

When the tannase produced by Pestalotiopsis guepinii URM 7114 was evaluated in vitro, it was noticed that the lower activity of $87.3 \%$ was found in the assay of total digestion. All other simulated tests potentiated tannase activity above $100 \%$. These results suggest that the tannase produced by $P$. guepinii can be appplied for the treatment of plants rich in tannins used as food for monogastric animals, since the digestive enzymes did not prevent enzymatic activity. Moreover, some researchers claim that the presence of digestive components in vivo can improve the performance of the enzyme (30).

The evaluation of simulation of in vitro digestion in the literature is extremely scarce. However, it was reported that the phytase produced by Mucor hiemalis had $77 \%$ of its original activity after the use of pepsin and $83 \%$ after the use of pancreatin and bile extract (30). In the study developed by Gomes et al. (31), phytase retained $66.98 \%$ stability under in vitro simulation of digestion using trip$\sin$. In that work the influence of total digestion was not evaluated, as was done in the present work.

As previously mentioned, besides the application under simulated gastric conditions, the enzyme can be used in instant tea, which provides a reduction of turbidity and increases the concentration of volatile phenolic compounds, promoting the quality of both hot and cold tea (56). In some fruit juices, tannase is used to remove phenolic compounds and prevent their complexation and precipitation $(57,58)$. Besides reduced stringency, which improves the acceptance of a beverage, the use of the enzyme retards the oxidation of vitamin $C$, thus increasing its antioxidant properties $(34,59)$. Other potential applica- 
tions of tannase are found as an additive in the manufacture of laundry detergents (60).

However, there are some limitations such as recovery, reuse and continuous use of free tannase, and several attempts have been made to immobilize the enzyme on a suitable matrix. Alginate beads are reported to be one of the most popular carriers for enzyme immobilization. Immobilization of tannase from Aspergillus heteromorphus was studied on DEAE-Sephadex A-50 and calcium alginate by Chhokar et al. (61) for commercial use in food industries. In a research by Srivastava and Kar (62), tannase produced by Aspergillus niger was immobilized on sodium alginate beads and applied for tannin removal from myrobalan (Phyllanthus emblica) juice, while Su et al. (63) immobilized tannase from Aspergillus ficuum to investigate its haze-removing effect from tea beverage. Gallic acid was isolated from tannase produced by Aspergillus niger by entrapment in sodium alginate, and used in the production of an antibacterial drug Trimethoprim (64)

Improvement in productivity of tannase can be done by manipulating the nutritional and physical parameters in the fermentation, such as $\mathrm{pH}$, incubation temperature, inducers and agitation. Tannase is reported to be an inducible enzyme produced in the presence of tannic acid. However, other compounds such as gallic acid, ethyl gallate, isoamyl gallate, propyl gallate and methyl gallate have also been reported to possess inductive properties. However, inhibition of the formation of tannase by catabolite repression or feedback inhibition can be observed $(15,65)$.

The use of different statistical models for the optimization of enzyme production has been successfully employed and proven to be a powerful tool in optimizing the variables for bioprocess improvements. However, tannase production processes have been carried out mainly using shake flasks in both submerged and solid-state fermentations. Fewer laboratory studies have been carried out in laboratory-scale fermentors. The optimization of tannase production by $A$. niger was carried out in packed-bed bioreactors using polyurethane. The use of Box-Behnken design helped to increase the enzyme activity about 1.97 -fold, from 4.03 to $7.96 \mathrm{U} / \mathrm{L}$ (66). The optimization of tannase production by Lactobacillus plantarum CIR1 was carried out following the Taguchi method. Tannase production was further carried out in an airlift bioreactor. A 5.17- and 8.08-fold increase in the enzyme production was observed by Aguilar-Zarate et al. (67). Moreover, the conditions for obtaining the maximal production of the enzyme depend on two factors: the system utilized and the source of the enzyme.

Literature data suggest that regulatory mechanisms and optimal conditions for tannase production can vary considerably depending on the microorganism, cultivation conditions, type of fermentation, free or immobilized enzyme and experimental process. Consequently, these findings can lead to the development of a fermentation system that is able to produce large amounts of tannase by Pestalotiopsis guepinii URM 7114 in economical, compact, and scalable reactors.

\section{Conclusions}

In the present work, we report for the first time the production of tannase by Pestalotiopsis guepinii URM 7114.
This study revealed differences in tannase produced under submerged, solid-state and slurry-state fermentations. Submerged fermentation was found to be the most promising. The study of endophytic fungi isolated from Syzygium cumini contributed to the identification of new microbial species that produces tannase. The results presented in this work show that $P$. guepinii tannase has interesting and attractive properties (low $K_{\mathrm{m}}$ thermostability, resistance to metal ions, chelators and detergents) for industrial applications such as preparation of instant tea, manufacture of laundry detergents, beverages like juices, and additives for feed industry. These results provide a basis for further study of large-scale fermentation for the production of tannase by $P$. guepinii.

\section{Acknowledgements}

We thank the Foundation for Science and Technology of the State of Pernambuco (FACEPE), Brazil, and to the Federal Institute of Education, Science and Technology of Pernambuco (IFPE), Campus Barreiros, for the awarded scholarships, and to Cristina Maria de Souza-Motta, curator of URM Culture Collection (WFCC 604), for identifying the microorganism. We also thank the Biotechnology Graduate Program (UEFS/FIOCRUZ).

\section{References}

1. M. Chandrasekaran, V. Venkatesalu, Antibacterial and antifungal activity of Syzygium jambolanum seeds, J. Ethnopharmacol. 91 (2004) 105-108. http://dx.doi.org/10.1016/j.jep.2003.12.012

2. H. Lorenzi, L. Bacher, M. Lacerda, S. Sartori: Brazilian and Exotic Cultivated Fruits (For Fresh Consumption), Plantarum Institute for the Study of Flora, São Paulo, Brazil (2006) (in Portuguese).

3. R. Kumar, J. Sharma, R. Singh, Production of tannase from Aspergillus ruber under solid-state fermentation using jamun (Syzygium cumini) leaves, Microbiol. Res. 162 (2007) 384-390.

http:/dx.doi.org/10.1016/j.micres.2006.06.012

4. M.K. Selwal, A. Yadav, K.K. Selwal, N.K. Aggarwal, R. Gupta, S.K. Gautam, Optimization of cultural conditions for tannase production by Pseudomonas aeruginosa IIIB 8914 under submerged fermentation, World J. Microbiol. Biotechnol. 26 (2010) 599-605. http://dx.doi.org/10.1007/s11274-009-0209-x

5. M. Vizzoto, M.C. Pereira: Characterization of the Functional Properties of Jambolan, Embrapa Temperate Agriculture, Pelotas, Brazil (2008) (in Portuguese).

6. C.N. Aguilar, C. Augur, G. Viniegra-González, E. Favela, A comparison of methods to determine tannin acyl hydrolase activity, Braz. Arch. Biol. Techn. 42 (1999) 355-361.

7. M.A.T. Santos, Chemical characterization of the leaves of broccoli and cauliflower (Brassica oleracea L.) for use in food, PhD Thesis, Federal University of Lavras, Lavras, MG, Brazil (2000) (in Portuguese).

8. P.K. Lekha, B.K. Lonsane, Comparative titres, location and properties of tannin acyl hydrolase produced by Aspergillus niger PKL 104 in solid-state, liquid surface and submerged fermentations, Process Biochem. 29 (1997) 497-503. http://dx.doi.org/10.1016/0032-9592(94)85019-4

9. S.S.N. Maharachchikumbura, L.D. Guo, E. Chukeatirote, A.H. Bahkali, K.D. Hyde, Pestalotiopsis - Morphology, phylogeny, biochemistry and diversity, Fungal Divers. 50 (2011) 167-187.

http://dx.doi.org/10.1007/s13225-011-0125-x 
10. D. Banerjee, K.C. Mondal, B.R. Pati, Production and characterization of extracellular and intracellular tannase from newly isolated Aspergillus aculeatus DBF 9, J. Basic Microbiol. 41 (2001) 313-318.

http://dx.doi.org/10.1002/1521-4028(200112)41:6<313::AIDJOBM313>3.0.CO;2-W

11. V. Battestin, G.A. Macedo, Tannase production by Paecilomyces variotii, Bioresour. Technol. 98 (2007) 1832-1837. http://dx.doi.org/10.1016/j.biortech.2006.06.031

12. A. Robledo, A. Aguilera-Carbó, R. Rodriguez, J.L. Martinez, Y. Garza, C.N. Aguilar, Ellagic acid production by Aspergillus niger in solid state fermentation of pomegranate residues, J. Ind. Microbiol. Biotechnol. 35 (2008) 507-513. http://dx.doi.org/10.1007/s10295-008-0309-x

13. B. Mahendran, N. Raman, D.J. Kim, Purification and characterization of tannase from Paecilomyces variotii: Hydrolysis of tannic acid using immobilized tannase, Appl. Microbiol. Biotechnol. 70 (2006) 444-450. http://dx.doi.org/10.1007/s00253-005-0082-y

14. O.M. Nuero, F. Reyes, Enzymes for animal feeding from Penicillium chrysogenum mycelial wastes from penicillin manufacture, Lett. Appl. Microbiol. 34 (2002) 413-416. http://dx.doi.org/10.1046/j.1472-765X.2002.01113.x

15. C.N. Aguilar, G. Gutierrez-Sanchez, Review: Sources, properties, applications and potential uses of tannin acyl hydrolase, Food Sci. Technol. Int. 7 (2001) 373-382. http://dx.doi.org/10.1106/69M3-B30K-CF7Q-RJ5G

16. S. Bradoo, R. Gupta, R.K. Saxena, Screening of extracellular tannase-producing fungi: Development of a rapid and simple plate assay, J. Gen. Appl. Microbiol. 42 (1996) 325-329. http://dx.doi.org/10.2323/jgam.42.325

17. R. Paranthaman, R. Vidyalakshmi, S. Murugesh, K. Singaravadivel, Optimization of various culture media for tannase production in submerged fermentation by Aspergillus flavus, Adv. Biol. Res. 3 (2009) 34-39.

18. G.A. Strobel, Endophytes as sources of bioactive products, Microb. Infect. 5 (2003) 535-544. http://dx.doi.org/10.1016/S1286-4579(03)00073-X

19. B. Schulz, S.D. Wanke, H.J. Aust, Endophytes from herbaceous plants and shrubs: Effectiveness of surface sterilization methods, Mycol. Res. 12 (1993) 1447-1450. http://dx.doi.org/10.1016/S0953-7562(09)80215-3

20. W. Photita, S. Lumyong, P. Lumyong, K.D. Hyde, Endophytic fungi of wild banana (Musa acuminata) at Doi Suthep Pui National Park, Thailand, Mycol. Res. 105 (2001) 1508-1513. http://dx.doi.org/10.1017/S0953756201004968

21. G.H. Karaca, I. Erper, First report of Pestalotiopsis guepinii causing twig blight on hazelnut and walnut in Turkey, Plant Pathol. 50 (2001) 415. http://dx.doi.org/10.1046/j.1365-3059.2001.00580.x

22. K.D. Hyde, J. Fröhlich, Mycosphaerella palmicola associated with leaf spots of Cocos nucifera in Australia Iran Jaya and Papua New Guinea, Mycol Res. 99 (1995) 704-706. http://dx.doi.org/10.1016/S0953-7562(09)80532-7

23. M.C. Rivera, E.R. Wright, First report of azalea petal blight caused by Pestalotiopsis guepinii in Argentina, Plant Dis. 84 (2000) 100. http://dx.doi.org/10.1094/PDIS.2000.84.1.100C

24. F. Yasuda, T. Kobayashi, H. Watanabe, H. Izawa, Addition of Pestalotiopsis spp. to leaf spot pathogens of Japanese persimmon, J. Gen. Plant Pathol. 69 (2003) 29-32. http://dx.doi.org/10.1007/s10327-002-0011-1

25. A.H. Aly, A. Debbab, J. Kjer, P. Proksch, Fungal endophytes from higher plants: A prolific source of phytochemicals and other bioactive natural products, Fungal Divers. 41 (2010) $1-16$.

http://dx.doi.org/10.1007/s13225-010-0034-4
26. J. Xu, S.S. Ebada, P. Proksch, Pestalotiopsis a highly creative genus: Chemistry and bioactivity of secondary metabolites, Fungal Divers. 44 (2010) 15-31.

http://dx.doi.org/10.1007/s13225-010-0055-z

27. G.L. Maria, K.R. Sridhar, N.S. Raviraja, Antimicrobial and enzyme activity of mangrove endophytic fungi of southwest coast of India, J. Agric. Technol. 1 (2005).

28. S. Sharma, T.K. Bhat, R.K.A. Dawra, Spectrophotometric method for assay of tannase using rhodanine, Anal. Biochem. 279 (2000) 85-89. http://dx.doi.org/10.1006/abio.1999.4405

29. G.A.S. Pinto, S. Couri, E.B. Gonçalves, Replacement of methanol by ethanol on gallic acid determination by rhodanine and its impacts on the tannase assay, Electron. J. Environ. Agric. Food Chem. 5 (2006) 1560-1568.

30. A. Boyce, G. Walsh, Purification and characterization of an acid phosphatase with phytase activity from Mucor hiemalis Wehmer, J. Biotechnol. 132 (2007) 82-87. http://dx.doi.org/10.1016/j.jbiotec.2007.08.028

31. J.E.G. Gomes, T.C.E.S. Nascimento, A.E.S.F. Queiroz, J.I.S.S. Júnior, C.M. Souza-Motta, E.V. Medeiros et al., Production, characterization and evaluation of in vitro digestion of phytases, xylanases and cellulases for feed industry, Afr. J. Microbiol. Res. 8 (2014) 551-558. http://dx.doi.org/10.5897/AJMR2013.6299

32. H.S. Hamdy, E.M. Fawzy, Economic production of tannase by Aspergillus niger van Tiegh adopting different fermentation protocols and possible applications, Rom. Biotech. Lett. 17 (2012) 7441-7457.

33. J. Renovato, G. Gutiérrez-Sánchez, L.V. Rodríguez-Durán, C. Bergman, R. Rodríguez, C.N. Aguilar, Differential properties of Aspergillus niger tannase produced under solid-state and submerged fermentations, Appl. Biochem. Biotechnol. 165 (2011) 382-395.

http://dx.doi.org/10.1007/s12010-011-9258-3

34. A. Srivastava, R. Kar, Characterization and application of tannase produced by Aspergillus niger ITCC 6514.07 on pomegranate rind, Braz. J. Microbiol. 40 (2009) 782-789. http://dx.doi.org/10.1590/S1517-83822009000400008

35. Y. Qiu, H. Niu, W. Huang, Y. He, Xiao-Hua. Wu, Properties and secondary structure of tannase from Penicillium herquei, Biotechnol. Bioprocess Eng. 16 (2011) 858-866. http://dx.doi.org/10.1007/s12257-011-0123-6

36. A.J. Riul, H.B. Gonçalves, J.A. Jorge, L.H.S. Guimarães, Characterization of a glucose- and solvent-tolerant extracellular tannase from Aspergillus phoenicis, J. Mol. Catal. B: Enzym. 85-86 (2013) 126-133. http://dx.doi.org/10.1016/j.molcatb.2012.09.001

37. A.M. da Costa, M.K. Kadowaki, M.C. Minozzo, C.G.M. de Souza, C.G. Bôer, A. Bracht, R.M. Peralta, Production, purification and characterization of tannase from Aspergillus tamarii, Afr. J. Biotechnol. 2 (2012) 391-398.

38. M.K. Selwal, K.K. Selwal, High level tannase production by Penicillium atramentosum KM using agro residues under submerged fermentation, Ann. Microbiol. 62 (2011) 139-148. http://dx.doi.org/10.1007/s13213-011-0238-1

39. A. Sabu, G.S. Kiran, A. Pandey, Purification and characterization of tannin acyl hydrolase from Aspergillus niger ATCC 16620, Food Technol. Biotechnol. 43 (2005) 133-138.

40. V. Chhokar, Seema, V. Beniwal, R.K. Salar, K.S. Nehra, A. Kumar, J.S. Rana, Purification and characterization of extracellular tannin acyl hydrolase from Aspergillus heteromorphus MTCC 8818, Biotechnol. Bioprocess Eng. 15 (2010) 793-799. http://dx.doi.org/10.1007/s12257-010-0058-3

41. R.N. Bhoite, P.N. Navya, P.S. Murthy, Purification and characterisation of a coffee pulp tannase produced by Penicillium verrucosum, J. Food Sci. Eng. 3 (2013) 323-331. 
42. R.H. Sajedi, H. Naderi-Manesh, K. Khajeh, R. Ahmadvand, B. Ranjbar, A. Asoodeh, F. Moradian, A Ca-independent $\alpha$-amylase that is active and stable at low $\mathrm{pH}$ from the Bacillus sp. KR-8104, Enzyme Microb. Technol. 36 (2005) 666-671. http://dx.doi.org/10.1016/j.enzmictec.2004.11.003

43. E. Bismuto, R. Nucci, F. Febbraio, F. Tanfani, F. Gentile, R. Briante et al., Effects induced by mono- and divalent cations on protein regions responsible for thermal adaptation in $\beta$-glycosidase from Sulfolobus solfataricus, Eur. Biophys. J. 33 (2004) 38-49. http://dx.doi.org/10.1007/s00249-003-0350-7

45. K. Aoki, R. Shinke, H. Nishira, Purification and some properties of yeast tannase, Agr. Biol. Chem. 40 (1976) 79-85. http://dx.doi.org/10.1271/bbb1961.40.79

46. H. Iqbal, A. Kapoor, Tannin degradation efficiency of tannase produced by Trichoderma harzianum MTCC 10841 and its biochemical properties, Int. J. LifeSc. Bt \& Pharm. Res. 1 (2012) 106-117.

47. H.B. Gonçalves, A.J. Riul, A.C. Quiapim, J.A. Jorge, L.H.S. Guimarães, Characterization of a thermostable extracellular tannase produced under submerged fermentation by Aspergillus ochraceus, Electron. J. Biotechn. 15 (2012) 1-12.

48. A.B. El-Tanash, A.A. Sherief, A. Nour, Catalytic properties of immobilized tannase produced from Aspergillus aculeatus compared with the free enzyme, Braz. J. Chem. Eng. 28 (2011) 381-391. http://dx.doi.org/10.1590/S0104-66322011000300004

49. M. Mata-Gómez, L.V. Rodríguez, E.L. Ramos, J. Renovato, M.A. Cruz-Hernandéz, R. Rodríguez et al., A novel tannase from the xerophilic fungus Aspergillus niger GH1, J. Microbiol. Biotechnol. 19 (2009) 987-996. http://dx.doi.org/10.4014/jmb.0811.615

50. E. Zakipour-Molkabadi, Z. Hamidi-Esfahani, M.A. Sahari, M.H. Azizi, A new native source of tannase producer, Penicillium sp. EZ-ZH190: Characterization of the enzyme, Iran. J. Biotech. 11 (2013) 244-250. http://dx.doi.org/10.5812/ijb.11848

51. A. Flores-Maltos, L.V. Rodríguez-Durán, J. Renovato, J.C. Contreras, R. Rodríguez, C.N. Aguilar, Catalytical properties of free and immobilized Aspergillus niger tannase, Enzyme Res. 2011 (2011) Article ID 768183. http://dx.doi.org/10.4061/2011/768183

52. H.B. Gonçalves, A.J. Riul, H.F. Terenzi, J.A. Jorge, L.H.S. Guimarães, Extracellular tannase from Emericella nidulans showing hypertolerance to temperature and organic solvents, J. Mol. Catal. B: Enzym. 71 (2011) 29-35. http://dx.doi.org/10.1016/j.molcatb.2011.03.005

53. S. Gayem, U. Ghosh, Purification and characterization of tannin acyl hydrolase produced by mixed solid state fermentation of wheat bran and marigold flower by Penicillium notatum NCIM 923, BioMed Res. Int. 2013 (2013) Article ID 596380. http://dx.doi.org/10.1155/2013/596380

54. M.Z. El-Fouly, Z. El-Awamry, A.AM. Shahin, H.A. El-Bialy, E. Naeem, G.E El-Saeed, Biosynthesis and characterization of Aspergillus niger AUMC 4301 tannase, J. Am. Sci. 6 (2010) 709-721.
55. M.M. Roushdy, S.E. Desouky, M.E. Esmael, S.S. El-Louboudy, H.H. Elshikh, Optimization and characterization of tannin acyl hydrolase produced by Aspergillus flavus var. columnaris using solid state fermentation technique, New York Sci. J. 7 (2014) 88-98.

56. P.K. Lekha, B.K. Lonsane, Comparative titres, location and properties of tannin acyl hydrolase produced by Aspergillus niger PKL 104 in solid-state, liquid surface and submerged fermentations, Process Biochem. 29 (1994) 497-503. http://dx.doi.org/10.1016/0032-9592(94)85019-4

57. C.N. Aguilar, R. Rodríguez, G. Gutiérrez-Sánchez, C. Augur, E. Favela-Torres, L.A. Prado-Barragan, A. Ramírez-Coronel, J.C. Contreras-Esquivel, Microbial tannases: Advances and perspectives, Appl. Microbiol. Biotechnol. 76 (2007) 47-59. http://dx.doi.org/10.1007/s00253-007-1000-2

58. N.K. Sharma, V. Beniwal, N. Kumar, S. Kumar, A.K. Pathera, R. Aradhita, Production of tannase under solid-state fermentation and its application in detannification of guava juice, Prep. Biochem. Biotechnol. 44 (2014) 281-290. http://dx.doi.org/10.1080/10826068.2013.812566

59. S. Rout, R. Banerjee, Production of tannase under mSSF and its application in fruit juice debittering, Indian J. Biotechnol. 5 (2006) 346-350.

60. A.T. Brooker, R.N.P. Somerville, G.S. Miracle, N.J. Lant, P.F. Souter, M. Forrest, C. Ure, A catalytic laundry detergent composition comprising relatively low levels of water-soluble electrolyte. US patent 0005003 (2011).

61. V. Chhokar, S. Katiyar, V. Beniwal, A. Kumar. J.S. Rana, Immobilization of tannase for commercial use in food industries, Asian J. Biosci. 3 (2008) 275-278.

62. A. Srivastava, R. Kar, Application of immobilized tannase from Aspergillus niger for the removal of tannin from myrobalan juice, Indian J. Microbiol. (Suppl. 1), 50 (2010) 46-51. http://dx.doi.org/10.1007/s12088-010-0029-6

63. E. Su, T. Xia, L. Gao, Q. Dai, Z. Zhang, Immobilization and characterization of tannase and its haze-removing, Food Sci. Technol. Int. 15 (2009) 545-552. http://dx.doi.org/10.1177/1082013209352919

64. B.L. Kumar, N. Lokeswari, D. Sriramireddy, Immobilization of tannin acyl hydrolase from Aspergillus niger, Int. J. Pharm. Sci. Res. 4 (2013) 1485-1487.

65. P.D. Belur, G. Mugeraya, Microbial production of tannase: State of the art, Res. J. Microbiol. 6 (2011) 25-40. http://dx.doi.org/10.3923/jm.2011.25.40

66. L.V. Rodríguez-Duran, J.C. Contreras-Esquivel, R. Rodríguez, L.A. Prado-Barragán, C.N. Aguilar, Optimization of tannase production by Aspergillus niger in solid-state packed-bed bioreactor, J. Microbiol. Biotechnol. 21 (2011) 960-967. http://dx.doi.org/10.4014/jmb.1103.03025

67. P. Aguilar-Zarate, M.A. Cruz-Hernandez, J.C. Monta-ez, R.E. Belmares-Cerda, C.N. Aguilar, Enhancement of tannase production by Lactobacillus plantarum CIR1: Validation in gaslift bioreactor, Bioprocess Biosyst. Eng. 37 (2014) 2305-2316. http://dx.doi.org/10.1007/s00449-014-1208-3 